\title{
The Politics of International Terrorism in the Security Complexes in the Greater Horn of Africa: An Overview from Uganda under the Movementocracy
}

Aaron K.K. Mukwaya*

\begin{abstract}
The article attempts to analyse the phenomenon of international terrorism in the Greater Horn Security Complexes, with the emphasis on the role of Uganda's Movementocratic government. The article is premised on the thesis that 'International Terrorism', apart from its local, national, regional and global causes, has become one of the key determinants of foreign policy and regional relations in the Greater Horn of Africa, and even more so for Uganda. It asserts that given the uniqueness of the Movementocracy and the global appraisal of this governance, Uganda is at the moment standing up to be counted by western countries as one of the vanguards in the fight against international terrorism in the Greater Horn of Africa. It also considers the causes and consequences of international terrorism and the methodologies and strategies for addressing this political scourge at the local, national, regional, continental and global levels. Here we shall examine unilateral, bilateral and multilateral approaches in dealing with international terrorism through states and non-states arrangements and methodologies.
\end{abstract}

\section{Résumé}

Cet article tente d'analyser le phénomène du terrorisme international dans les Greater Horn Security Complexes (complexes de sécurité dans la région de la Grande Corne de l'Afrique), en insistant sur le rôle du gouvernement mouvementocratique de l'Ouganda. Cet article part de l'hypothèse que mis à part ses causes locales, nationales, régionales et mondiales, le « Terrorisme International » est devenu un des principaux déterminants de la politique étrangère et des relations régionales dans la région de la Grande Corne de l'Afrique, et en Ouganda. L'auteur affirme

* International Relations and Security Studies, Department of Political Science and Public Administration, Makerere University, Kampala, Uganda. 
qu'étant donné le caractère unique de la Mouvementocratie et l'évaluation mondiale faite de ce mouvement, l'Ouganda est en passe d'être considéré par les pays occidentaux comme une des nations à l'avant-garde de la lutte contre le terrorisme international, dans la région de la Grande Corne de l'Afrique. L'article analyse également les causes et conséquences du terrorisme international ainsi que les méthodologies et stratégies de lutte contre ce fléau politique à l'échelle locale, nationale, régionale, continentale et mondiale. Dans le cadre de ce travail, nous examinerons les différentes approches unilatérales, bilatérales et multilatérales de lutte contre le terrorisme international, à travers des dispositions et méthodologies étatiques et non étatiques particulières.

\section{Introduction}

The article is concerned with the current global issue of terrorism. It should be noted that terrorism has manifested itself in various forms in Uganda, Africa and globally. At the local level, expressions of lawlessness, taking the laws into people's hands, and people operating in politically chaotic situations have all been common in Uganda. At the national level, terrorism has been practised in two forms. First, Uganda has experienced state terrorism in many ways. In some instances, governments failed to run the country on the basis of the rule of law and human rights. Uganda has been bedevilled with a history of torture, torment and traumatisation of its people by governments.

Uganda has also experienced internal terrorism through rebel activities, tribal killings in Kibaale, and bombardments through urban terrorism in Kampala. The other dimensions of state/international terrorism are found in Uganda. And lastly, state/international terrorism is expressed in human rights violations and mayhem during Uganda's invasion of other countries in the region. The most striking examples of Uganda's encounter with international terrorism were in June 1976 and the politics of the war on terror (Al Qaeda). In 1976, Palestinian terrorists hijacked an Air France airbus with 258 passengers outside Athens. The airbus was piloted to Entebbe airport in Uganda. During the debacle, the internal terror machine of President Idi Amin embraced the actions of the Palestinian hijackers. The debacle ended with an episode known as the Israeli Entebbe raid, code named 'Operation Thunderbolt'.

The present state of international terrorism is what I have termed as 'Global terrorism made in the USA'. It is Al Qaeda terrorism against Western, especially US, interests globally as well as the reactions of Western countries and chain reactions of developing countries to the new non-state international terrorism. Global terrorism Made in the 
USA is defined by the rich and politically powerful countries. For instance, the American government defines its enemies and puts them on or off the list of terrorists as it so wishes. The US then uses its money to force the developing and other developed countries to swallow their definitions, actions and reactions. The Patriot Act is the road map of the anti-terrorism crusade. Both sides use religious rhetoric in their pursuit of the policy of 'With US or with the Enemy'. Even liberation movements were labelled terrorist organisations by the West. For example, the British government for a long time considered the ANC of South Africa a terrorist organisation.

International terrorism is, therefore, both an action and reaction to a depressing, desperate, hopeless and excluding situation. The actions and reactions take on political, economic, social, ideological, psychological, emotional and religious fervour. Terrorist activities against civilians and military personnel aim at visibility, recognition and the creation of fear and panic. As a result of certain terrorist activities, the concept of 'non-state actors' has acquired a negative connotation in international relations.

At the moment there are more than nineteen $\mathrm{UN}$ and international conventions which deal with international terrorism in one way or the other. It was not until the Al Qaeda 9/1 l episode that an attempt to reach an overriding definition was put into question. The most acceptable definition continues to pre-occupy politicians, lawyers, administrators and academia. National Anti-Terrorism Acts (balancing between national security and civil liberties) have continued to grapple with a proper definition as well. This article aims at examining and analysing the politics of international terrorism from the Movementocracy point of view.

The governance of Movementocracy is a direct result of the armed struggle of the National Resistance Army (NRA) and the National Resistance Movement (NRM) in Uganda, which were fused to bring about the political concoction which ravaged the country for more than five years. The Luwero Triangle Bush War, as it came to be known, drew the country into yet another outbreak of political rebellion. The 1980s and 1990s experienced a region-wide wave of politically motivated rebel movements and activities, which culminated in some unique political regimes in the Greater Horn of Africa and the Great Lakes region. Countries which experienced such upsurges included Uganda, Ethiopia, Eritrea, Rwanda, the DRC, Burundi, and Sudan. 
The region-wide wave of rebel activities was ignited by domestic, regional and global factors which were dynamically changing as a result of the rapid transition from the Cold War to the Post-Cold War era. The Greater Horn of Africa, and Africa as a whole, were afflicted by a generation of violent regime changes, not through state organs, but nonstate actors. The military coups d'Ettat were replaced with protracted guerrilla movements, which ended with the 'New Breed' of African leaders controlling state power.

Given the similarities of guerrilla warfare and the culminating new rebel regimes, one is tempted to argue that there are more commonalities than divergences in the region. The new developments in the region and Africa have inclined scholars to claim that Africa is experiencing a Renaissance (New Rebirth), a Second Liberation, a New Revolution and a Success Story engineered by the New Breed of African leadership. However, the changing dynamics at the domestic, regional and global levels have produced very unpredictable and unprecedented nonstate actors, who pose violent and radical challenges to the real foundations and existence of the nation-state system itself.

Increased domestic and regional unpredictability, instability and insecurity have become characteristic of the politics of the Greater Horn of Africa. The region is embroiled in increased rebel activities, warlordism, interstate and intrastate conflicts, cattle rustling, cross-border makeshift incursions, fundamentalism, resurfacing sub-chauvinistic nationalisms, boundary disputes, wars and international terrorism. These, and much more, drain efforts and resources for nation-building and regional cooperation, security and development. Several countries are the arena of state and regime survival. Many attempts to address these new challenges have taken on multiple dimensions at the national, regional and global levels; but solutions are not easily found.

The article attempts to analyse the phenomenon of international terrorism in the Greater Horn Security Complexes, with the emphasis on the role of Uganda's Movementocratic government. The article is premised on the thesis that 'International Terrorism', apart from its local, national, regional and global causes, has become one of the key determinants of foreign policy and regional relations in the Greater Horn of Africa, and even more so for Uganda.

It asserts that given the uniqueness of the Movementocracy and the global appraisal of this governance, Uganda is at the moment standing up to be counted by western countries as one of the vanguards in the 
fight against international terrorism in the Greater Horn of Africa. It also considers the causes and consequences of international terrorism and the methodologies and strategies of addressing this political scourge at the local, national, regional, continental and global levels. Here we shall examine unilateral, bilateral and multilateral approaches in dealing with international terrorism through states and non-states arrangements and methodologies.

The nation-states in the Greater Horn of Africa are battling with the problems and politics of nation building, national and region integration and unity, security, stability, markets and development. To achieve their goals, the phenomenon of international terrorism need to be addressed head on by Uganda and the region itself without succumbing to external pressures and without sacrificing national and regional interests.

The data used in the article is drawn from ongoing research on 'Uganda's foreign policy under the Movementocracy' by the author. The article considers the Realist Theory in international relations and applies it in a wider development thinking perspective. Since the two place great emphasis on power, power relations, security and actors, the article attempts to unveil a new outlook for studying foreign policy in Africa.

\section{Re-defining the Greater Horn of Africa}

It is essential that we attempt an analytical understanding of the concept and region referred to as the Greater Horn of Africa. In this way, we shall be able to map out the main actors (states and non-statesactors) and elements that condition the new dynamics in the region. The Greater Horn of Africa is a region with certain commonalities. The countries identified in the region include Ethiopia, Eritrea, Djibouti, Somalia, Sudan, Uganda, Kenya, Tanzania and Egypt. We need to trace the origins and development of the concept in order to analyse contemporary international relations in the Greater Horn of Africa.

Historically, the Greater Horn must be examined within the context of the water systems of the River Nile, the Red Sea, the Indian Ocean, the Mediterranean Sea, and Lake Victoria. These countries lie in the Horn-shaped North-Eastern tip of the African continent. In this geographical context:

Uganda sits on the top of the waters of the largest Lake in Africa - Lake Victoria, and the source of the River Nile. This location made Uganda unique and strategically important to the colonial adventurisms. The 
struggle between the British, Belgians, Germans, Portuguese, Spaniards and the French were centred around the River Nile water sytems. ${ }^{1}$

The source of the White Nile is in Uganda. The White Nile is joined by the Blue Nile from Ethiopia through Sudan to Egypt where it flows into the Mediterranean Sea. The River Nile systems connects and brings Uganda even closer to Sudan, Egypt, Eritrea, Ethiopia and Djibouti. Lake Victoria, the source of the Nile, is Africa's largest inland water body, connecting the traditional three East African states of Uganda, Kenya and Tanzania. The influence of all these bodies of water on Uganda's relationships in the Greater Horn of Africa dates back to the precolonial era.

Uganda is not only a land-locked country but also its immediate hinterland states - Rwanda, Burundi and the Democratic Republic of Congo (DRC) - use it as a transit state to the Kenyan and Tanzanian Indian Ocean ports. The port of Mombasa is the lifeline of Uganda's economy. Anglophone interests and influences have predominated in the Greater Horn. Almost all the countries in the region were under British colonial rule. The only exception was French Somaliland and the temporary Italian influence in Ethiopia. Historically, the height of the scramble for Africa was centred in this region. For example, the Fashoda Incident ( 1899) between the British and the French; the struggle between the Germans and the British; as well as that between the British and the Belgians, were concentrated in this region.

Politically, it has been argued that the Greater Horn of Africa contains one country of immense historical significance. Ethiopia was the only country which was not colonised, although briefly occupied. It is a country with traditional links with the Jews - the 'Black Jews' or Falashas in Israel. It is also a country which had an Emperor with connections to the Middle East and Africans in the Diaspora; and a country, which houses the headquarters of the African Union (AU), formerly the Organisation of African Unity. Even after the Second World War, Uganda was suggested as a resettlement area for the Jews in diaspora in Europe.The Movementocracy, which was equipped with a new PanAfricanist agenda, found it easy to demystify and demythologise the colonial dichotomies in the Greater Horn. Here Anglophone influences were dominant, in contrast to the Great Lakes region where the clashes between Anglophones and Francophones are visible and real. The Movementocracy was of the view that such dichotomies were a danger to national and regional security and development. ${ }^{2}$ 
The geographical overlap of the Greater Great Lakes region, the Great Lakes region, and the Greater Horn of Africa is indicative of the fact that these regions are mere geopolitical expressions. The Greater Great Lakes region consists of Uganda, Kenya, Tanzania, Rwanda, Burundi, the Sudan, Democratic Republic of Congo and the Horn of Africa. ${ }^{3}$ The Greater Horn of Africa takes in parts of countries from the Great Lakes region and adds them to the traditional Horn of Africa (Ethiopia, Djibouti, Eritrea, Somalia and Sudan). Most of the traditional Horn of Africa possesses poor soils and vegetation, mountain ranges with several intermittent water bodies, except for the perennial Blue Nile. The region experiences hunger and famine, cattle rustling, seasonal migrations in search of grazing lands and water, and cross-border clashes. Here clan systems are very strong, developing into what we might term as 'clanocracies'. Clanocracies are based on chauvinistic sub-nationalisms, and have led to warlordism in the region. This type of social organisation has undermined the foundations of national sovereignty and nationalism, in turn frustrating nation building and regional cooperation.

In the area of security, the Greater Horn is knit together into a kind of common destiny of alternating insecurity and cooperation. There have been many crises in the region, with local and global dimensions. Two types of conflict have been common: intra-and inter-state conflicts. These are state-based conflicts. However, non-state conflicts are also very common. Conflicts over grazing lands, water, and cattle rustling also run through Uganda, Kenya, Sudan and Ethiopia. The Southern Sudanese conflict encompasses Sudan, Uganda, Kenya, Eritrea, Ethiopia, while the Lord's Resistance Army (LRA) involves Uganda and Sudan. In 2001 Ethiopia and Eritrea went to war over the Badme border area. The end of the rulership of Siad Barre led to the dismemberment of the Somali Republic in 1991 giving rise to warlordism and clanocracies in Somali.

The Greater Horn of Africa has also become the African centre of international terrorism and violent fundamentalism. This state of affairs has led to new Great Power interest in the region and in the long run it refuels an already insecure situation.The Greater Horn has also been a theatre for violent scenes in the political history of Africa: civil wars, rebel activities, military coups, guerrilla movements, ethnic and racial insurgencies, human rights violations, and drugs and arms trafficking. This makes the region one of the most unstable and insecure 
on the continent at the moment. The questions of nation building, security, cooperation, image building and development remain central for the region. The current inter-state, intra-state and non-states conflicts have not only riveted the world's attention on the region, but also helped to broaden the nature and scope of events in the Greater Horn of Africa.

The region is also characterised by marauding rebel movements. Nearly all rebel activities operate across the borders of two or more countries. Intense suspicion, mistrust and misunderstanding are rampant in the region. Accusations and counter accusations about states aiding rebels to destabilise other states abound. The agendas of the rebel groups, which include propaganda, training, arming and even financial assistance, run across the borders of several countries. The rebel movements, terrorism, fundamentalism as new non-state-actors have all heightened tensions and insecurity in the region. Most of the governments in the region are products of military coups and guerrilla wars. These rebelocracies and clanocracies have attempted to dupe the international community into believing that they intended to democratise. In return, the international community has glorified some leaders of the region as the New Breed of African leaders.

Given that there is an overlap between the so-called Great Lakes region and the Greater Horn of Africa, conflicts and insecurity tend to spill over from one part to another. The Greater Horn also enjoys a geographical proximity to the Middle East. The Middle East has remained the major hot spot in international relations. Being close to the Middle East has made the Greater Horn a backyard to the crisis in that region. The Arab/Non Arab factor is characteristic of the dynamics of the Greater Horn. Islamic fundamentalism in the Arab world finds its way to the region, especially the Sudan, Kenya, Tanzania, Somalia, Uganda and Djibouti. The Muslim-Christian divide is highlighted by the conflict in the Southern Sudan. The struggle in the Southern Sudan between the rebel groups and the Sudanese government finds expression in racial, religious and political clashes.

The West, especially the United States and the United Kingdom, have extensive interests in the Middle East and the Greater Horn of Africa. The United States has military and intelligence bases in the Middle East as well as Djibouti and Kenya. The Middle Eastern oil resources and the existence of Israel make the region central to the United States and Western interests. Undemocratic regimes, rebel ac- 
tivities, collapsing states, and wars in the Greater Horn as well as the upsurge of fundamentalism and international terrorism centred in the Middle East bring renewed interest by Great Powers in the African region.

International terrorism has created new dynamics in the region. The West, led by the United States, has emerged with new policies, which are packaged for the region. At the same time, states in the region have responded by re-designing their domestic and foreign polices in the region and globally to accommodate new developments resulting from international terrorism. On one hand, the West views the collapsing states and fundamentalism as some of the causes of terrorism in the region. On the other hand, states in the region are thrown into a scramble by the United States anti-terrorism programme. The Greater Horn has become an extension of the Middle East political hot spot.

\section{Uganda in the Greater Horn}

In examining the position of Uganda in conflict and security dilemmas in the Greater Horn of Africa, a look at some theoretical perspectives is essential in understanding the overall debate in its full context. It is true that Uganda is more a part of the Great Lakes region, and on the fringe of the Greater Horn of Africa. However, Uganda has also had pronounced political, diplomatic and military interests in the latter region. Under the Movementocracy Uganda has been able to manipulate resources in its pursuit of an assertive foreign policy in the Great Lakes region and the Greater Horn of Africa.

Let us now examine the factors that condition Uganda's position in the Greater Horn of Africa. First, when the region sank into political, economic, military and social crises and chaos, Uganda was no exception. Uganda has also had the lion's share of domestic and regional problems. Historically, Uganda only became a legal actor in the regional and international scenes in 1962 after more than six decades under British colonialism (Nnoli, 1992) ${ }^{4}$. The problems of colonialism and neo-colonialism are not only experienced in Uganda but also in the Greater Horn of Africa.

Uganda's geographical area is $241,138 \mathrm{sq} . \mathrm{km}$ of both land and water masses lying on the equator with a population of 24 million people. Uganda is a land-locked country bordering the Sudan to the North, 
Kenya to the East, and Tanzania to the South. The three bordering countries connect Uganda to the Greater Horn of Africa with its world system. To the Southwest, Uganda borders Rwanda, to the West the Democratic Republic of Congo (DRC). These two border states bring Uganda within the Great Lakes region. Like Rwanda, geographically Uganda is also a small country surrounded by very large countries. However, Uganda is endowed with fertile loam soils, and rainfall between $510 \mathrm{~mm}$ to $2160 \mathrm{~mm}$ well distributed throughout the year, giving it an edge on the other countries in the Great Horn of Africa. Apart from the favourable climate and weather, Uganda is also endowed with water and natural resources vital for development. Lake Victoria connects Uganda with Kenya and Tanzania. Through the River Nile water system, Uganda is connected to Sudan, Egypt, Ethiopia, Eritrea and Rwanda. Uganda is the immediate hinterland of countries like Rwanda, Burundi, and DRC who use it as a transit country to the Kenyan and Tanzanian Indian Ocean seaports. Mombasa port remains a lifeline of Uganda's economy. Uganda is also one of the poorest countries of the world with GDP of $\$ 5.44$ billion and real per capita income of $\$ 1,370$.

The influence of the water bodies on Uganda's foreign policy in the security complexes in the Greater Horn has been crucial since pre-colonial times. The strategic nature of the River Nile has led to the formation of a number of cross-national organisations concerned with the management of the system: the Kagera Basin Organisation, the Nile River Initiative, Lake Victoria Initiative, the East African Community, and to some extent the Inter-Governmental Authority on Development (IGAD).

Since independence Uganda has in theory followed a foreign policy of non-alignment. During the Movementocracy, domestic and external factors and forces have dictated a discretional (even total) alignment in her regional and global foreign policy pursuits. ${ }^{5}$ The non-alignment foreign policy line emphasized existence and survival of newly independent states, by collectively or individually avoiding alignment with any of the two blocs:

new states, by refusing to identify themselves with any side, maintain their freedom of action. Indeed, they gain self-recognition by asserting themselves - at the very minimum on a verbal plane - against the great power. ${ }^{6}$ 
However, under the Movementocracy, Uganda strives to 'Always maintain an independent line in economics, politics, culture and foreign relations... Judge friend or foe according to how they relate to our own interests irrespective of the social systems prevailing in the various countries' $^{7}$

However, given the domestic, regional and global dynamics, Uganda's foreign policy is guided by an open alignment to the West, especially during the Cold War under the Movementocracy. ${ }^{8}$

While Uganda is a land-locked country, its geographical location has been used as an important, political weapon in its regional relations. Given its geopolitical and strategic location, Uganda has been able to use its transit position and the River Nile system to manipulate and amplify its role in the Great Horn security complexes.

Uganda's foreign policy in the Greater Horn of Africa has been influenced by several elements in its domestic sphere. The best conceived and most expertly executed foreign policy, drawing upon an abundance of material and human resources, must come to naught if it cannot also draw upon good government. When the NRA/M took over state power in 1986 from the elected government of Obote, there was a need to rebuild the country. Within one year of the Movementocracy, the Museveni regime abandoned Marxism-Leninist and idealistic rhetoric and fully embraced liberal-realist thinking and practice. Foreign policy is domestic policy pursued by other means; it is domestic policy carried beyond the boundaries of the state. Leaders use foreign policy to cushion domestic policy.

After putting Uganda in historical and contemporary perspective, let us now examine the application of the Realist Theory in a wider development agenda perspective with regard to the country's relations in the Greater Horn of Africa. Classical realism puts much emphasis on power as the determining factor in foreign policy. The state is considered the most important actor in foreign policy. Given that the African states were young, poor and vulnerable, if power is equated with might, then these state were unable to engage fully in 'realist' foreign policy. From the Eurocentric view, African states were mere absorbers and recipients of the shocks of global foreign policy.

The weakness of African states has led them to be consumers of the foreign policies of developed countries. According to Burton and Morgenthau, ${ }^{9}$ nations have elements of power that determine their interactive capacity in the community of nations. These elements must 
be weighty enough to influence the role of a state vis-à-vis other states. Since Africa lacks the capacity to exploit its resources to the full, it is unable to make its presence felt on the international scene as it might wish. It has also been argued that African states have real national interests, but the environment for pursuing them is controlled by developed countries. When one examines western conditionalities, the problems of debt, and the global interests of developed countries vis-à-vis developing ones, it may seem that the classical realists have a point.

However, in analysing African foreign policies, the neo-realist trends are more appropriate. Sanders argues that there cannot be 'a global harmony of interests' ${ }^{10}$ and therefore, in a situation where the international system lacks a world government, the nation-state can never be sure that it is safe from external attack. ${ }^{11}$ Africa and the Greater Horn have suffered from weak governments, rebel movements, fundamentalism, international terrorism, and western interference to the extent that the countries have not been able to build viable institutions and values for aggregating national interests.

The emergence of new actors and new regional and global situations demand new theoretical approaches to the study of regional relations. Applications of the Realist Theory within a wider development agenda perspective could be appropriate in explaining the new interactive relationships of Uganda in the Greater Horn of Africa.Given the country's violent political history as well as changing dynamics in the region and globally, the NRM embarked upon reformulating Ugandan foreign policy. The NRM administration has re-emphasised security as the core of its foreign policy. First and foremost, the NRM was of the view that its unique Movementocracy was under threat from the regimes in the Great Lakes region and the Greater Horn of Africa. The NRM was of the view that these regimes were potential aggressors which:

dominate and exploit any other state weaker than itself... The overriding objective of a given state's foreign policy must be the achievement and maintenance of its security. This need to ensure security in turn requires both a strong defensive posture and the construction of alliances with other states, which share similar security fears.

Ensuring security also requires that the state does all it can both to weaken the strategic position of its opponents, and to ensure that friendly governments are installed (or maintained in power); in essence, cyni- 
cal, self-regarding calculation based on the paramount need to preserve national security. ${ }^{12}$

Second, Uganda under the Movementocracy governance relied heavily on the military. The belief that state activity should be based on the strength of the army has made the country's foreign policy extremely militarised. At the domestic level, the Ministry of Foreign Affairs has been marginalised and excluded from mainstream foreign policy making. Instead, the State House Complex (Palacism), and the Ministries of Defence and Finance have taken over from the Ministry of Foreign Affairs.

Apart from spending more on defence, the NRM have built on and off alliances with states with similar fears. Alliances have been built with the Rwandan Patriotic Front (Rwanda), Meles Zanawi (Ethiopia), Afwereki (Eritrea) and Kabila I (DRC) in order to re-design the region. These leaders were former rebels who had fought themselves into state power to build rebelocracies in the region. The NRM administration has worked tooth and nail to ensure that regimes of its liking are installed in power in the region. However, disagreements and domestic and external pressures, have not helped the maintenance of such alliances. The ultimate objective of preserving national security has not been realised, but the new leaders have managed to concentrate state power around themselves.

Here we need to apply the Realist Theory in a wider development agenda perspective. The Agenda aims at 'bridging the gap between theory and practice'. ${ }^{13}$ Development thinking relates Power to (In)Security and Ex/Inclusion in analysing foreign policy. The perspective re-integrates foreign policy research on a global, regional, national and local level. ${ }^{14}$ For instance, globalisation and its ramifications play a major role. At the same time there exists a strong cultural impact that imposes a western style of thinking. ${ }^{15}$

By applying the Realist Theory within the wider development thinking perspective, new light is shed on theory searching and methodological re-assessment in the discipline of international relations. The development thinking perspective, like Realist Theory, pays attention to actor-oriented approaches where the capabilities and potentialities of the traditional and new actors influence and are influenced by structural changes at local and global levels. There is a need for new directions by the traditional and new actors in their policies and practices in coping 
with the new dynamics of foreign policy relations.In this kind of analysis, it is important to take into account the security implications by relating power positions and exclusions. The relationships between the two variables are major causes of insecurity locally, nationally, regionally and globally. At the same time, insecurity breeds further exclusion and marginalisation from the development process in the economic, social and political spheres. ${ }^{16}$

The Greater Horn of Africa, comprising weak states, is confronted with the problems and policies of democratisation, foreign influences, economic liberalisation, social flux and increasing instability. In Uganda, like in the region, elements that make up state power, the quality of the governmental structure that enables the state to stand up successfully, are weak or totally absent. A nation-state that lacks appropriate arrangements for governance is bound to suffer the prevalence of internal insecurity and conflict. ${ }^{17}$

Uganda's role in the region is seen within the region's communalities of conflict, turbulence and insecurity. This common destiny poses a challenge to national and regional security, coexistence, cooperation, conflict resolution and development, which are in short supply in the region. The communalities in the region compound into security complexes, which are comprised of 'Groups of states whose primary concerns link together sufficiently closely that their national security cannot realistically be considered apart from one another... Security complexes emphasize the inter-dependencies of rivalry as well as that of shared interests. ${ }^{18}$ The Realist Theory guides us in examining the role and position of Uganda in the security complexes in the Greater Horn of Africa.

\section{The Movementocracy within the Security Complexes in the Greater Horn}

The NRA/M bush war was a unique experiment in the region. It was the first successful rebel movement stationed in the middle of the country of origin to take over state political power. The conduct of the NRA/M rebels made the movementocracy acceptable at home but a bad example for the region. This state of affairs has made the development of rebelocracies regionally and internationally almost acceptable. This is a very different development in security at the national and regional levels. The NRA/M was also programmed to remove the old regimes in 
the region, in the process leading to mutual suspicion and mistrust. The personality of Museveni came under heavy scrutiny, and evoked considerable suspicion amongst regional and global leaders. In the case of Kenya, continued insecurity and instability in Uganda was seen as a threat to the stability of the East African region. The Kenyan government, led under President Moi, was fearful that increased bloodletting and rebel activities would spill over into the entire region. Instability in Uganda was a threat to Western interests in Kenya and the region. ${ }^{19}$

Uganda has all along been a major regional market for Kenya's products, which include western industries. The role of Uganda as a major market for Kenya is a consideration that needs to be kept in mind when looking at the stability and security of Uganda and the Greater Horn. ${ }^{20}$ As early as 1986, the government of Kenya drove Ugandan exiles out of the country on the ground that they were fomenting rebel activities in the region. There were also Kenyan exiles in Uganda who were receiving military and other assistance from the NRA/M in order to fight the Kenyan government. The famous Mwakenya and Onyango groups were stationed in Uganda. In 1987 Uganda and Kenya nearly went to war, with their soldiers deployed at the Busia border. The Moi government was determined to hit hard at Uganda's new administration. The situation only cooled after the diplomatic intervention of Britain and the EU.

Uganda's role in the Horn of Africa has been influenced by the NRM ideal of a New Pan-Africanist Movement, which emphasises assistance to regional neighbours to free themselves from old regimes and to stop the dismemberment of states in the region. The bottom line to such an ideal is stability and security of the region centred around the movementocratic governance. It is in this light that President Museveni travelled into the thick of the war in Somalia. This personal initiative to assist Somalia from collapsing into clanocracies was a clear manifestation of the Movementocracy's aim to build a stable and strong regional bloc.

However, the Somalia situation, has not improved since the end of the Siad Barre regime in 1991. The country continues to be divided among warlords in Puntland, Jubaland, Somaliland and Mogadishu. At the moment Uganda is one of the four main mediators concerned with Somalia through IGAD. This is a regional body in the Greater Horn to deal with economic, political and conflict issues. At the moment IGAD negotiations on Somalia are still taking place in Kenya. Uganda is also 
involved hand in hand with Djibouti, Kenya and other members in finding lasting solutions to the Somalia problem.

In the 1990s Uganda, Eritrea, Ethiopia, and to some extent Rwanda and the DRC were hailed by the west as stars of the African renaissance and the new African revolution. They were defined as the new breed of African leaders who were bent on transforming Africa and bringing about democracy and economic development. This bigger picture has been marred by the war between Ethiopia and Eritrea, the DRC wars, the Kony war, wars in the Southern Sudan, rebel activities, and failures in the economy and democratic transformation.

The post-Cold War period has unleashed new political forces, which need new solutions regionally and internationally. The Greater Horn of Africa has become the core of fundamentalism and international terrorism on the continent. Islamic fundamentalism has characterised the politics and the realpolitik of Sudan, Kenya, Uganda, Eritrea, Djibouti, Somalia and Tanzania, leading to the demand for new strategies in combating it. In Uganda, Islamic fundamentalism has been associated with the Allied Democratic Forces (ADF). This is the rebel organisation which terrorised Western Uganda in the 1990s forcing the government to send the army into the DRC in order to eliminate its bases. The ADF operated between Uganda, DRC and the Sudan. At the same time, Christian fundamentalism found expression in the Lord's Resistance Army of Joseph Kony.

The Ugandan government has condemned the Islamist Khartoum government for propping up fundamentalists. Uganda has pointed to Islamic fundamentalism in the Sudan as a way of demanding more assistance from the West. Uganda's foreign policy has therefore taken advantage of Islamic fundamentalism for its military, financial and economic benefit. Uganda's increased support of the Sudan People's Liberation Army (SPLA) has in part been guided by anti-fundamentalism and extremism in the Khartoum administration. Uganda's relations with Sudan in this aspect have also been guided by the new Pan-Africanist principles and agenda of the Movementocracy governance - support for the Southern brothers and sisters under the yoke of the Northerners in the Sudan. In 1995 Uganda even broke off diplomatic relations with Sudan, which were only resumed in 1999. Uganda continues to support the SPLA on the basis that the Khartoum government represents the old regimes which harnessed Islam to oppress the south. Uganda has 
also continued to accuse the Sudan Government of supporting the Lord's Resistance Army (LRA) of Joseph Kony.

Uganda has jumped on the US bandwagon of labelling the LRA as a terrorist organisation, and all its sponsors and supporters as terrorist collaborators. At a legal level, this situation makes it hard for the LRA to agree to negotiations outside Uganda and Sudan. However, the 1999 Protocol and 2002 Operation Iron Fist allowed the hot pursuit of the LRA inside the Sudan by the Ugandan Army. However, Iron Fist has only led to more havoc by the LRA in the North, to the extent that at the moment the LRA have driven deeper into the Lower North of Uganda (Lango) and the Far East (Teso). Accusations and counter accusations continue between Uganda and Sudan for equipping and giving safe haven to SPLA and LRA. The military approach of the Ugandan army has not provided a viable solution to the 18 year-old insurgency. There is a need for regional and international dialogue to resolve this problem. While the Ugandan government on its own initiative and through IGAD has advocated dialogue in the conflicts in Southern Sudan, Somalia, Ethiopia-Eritrea, DRC, and Burundi, it has not been keen on negotiating with the LRA.

\section{Uganda, the Greater Horn and International Terrorism}

Terrorism has been around in varying forms for centuries. However, the savagery of the new form of terrorism came into global prominence in what came to be known as September $11^{\text {th }}, 2001$. The end of the Cold War has unleashed forces which demand new outlooks and solutions. Even before 9/1 1, the US Embassies in Nairobi and Dar es Salaam had been attacked by terrorists in 1998 leading to a new era of terrorism in the Great Horn. Since these twin incidents, there have been increased tensions and security alerts in the region. The national and regional domestic and foreign policies and configuration of political forces have been dramatically changed and challenged.

In Uganda, the Parliament quickly passed the Anti-Terrorism Act, 2002 which defined terrorism as:

the use of violence or threat of violence with intent to promote or achieve political, religious, economic, and cultural or social ends in an unlawful manner, and includes the use of violence or threat of violence to put the public in fear or alarm. ${ }^{21}$ 
The Act in itself led to important developments with regard to domestic and foreign policy in Uganda. At the domestic level, the need to strive for stability and security prompted the passage of the Act. However, the over-arching definitions of terrorism in the Act tend to expose every act of violence to the label of terrorist, to the extent that public demonstrations or opposition group activities could be seen in terrorist terms.

At the foreign policy level, the Act emphasised the development of extradition arrangements with countries in the region and globally. The Act also seeks assistance and cooperation with other states in preventing and combating terrorism. Since the Bwindi Forest attack on tourists in Uganda, and the Nairobi-Dar-es-Salaam attacks, Uganda's security has been tightened. The British and American Diplomatic Missions were barricaded and enclosed like barracks. The US and British visa acquisition process became a real tug of war in Uganda and the Greater Horn.

It must be remembered that the US and Britain have military interests and establishments in Kenya and at Diego Garcia in the Indian Ocean, as well as economic and business interests in Kenya. US and British troops, as well as German, are stationed on the islands of Lamu, Kilindini and Mombasa. The military presence was increased after 9/ 11.The US and British government warned its citizens of the dangers of staying in Kenya after 9/1 I and the Mombasa Hotel bombing. British Airways even suspended its flights to Kenya and re-routed them to Uganda. In order to ensure that the Kenyan government was doing something in the fight against terrorism, all air travel to and from Somalia was suspended.

The relationship between Somalia and Kenya has not improved as the Kenyan government is witch hunting non-Kenyans, especially Moslems from Somalia, Ethiopia, Eritrea and Djibouti as terrorist suspects. In the district of Mombasa, there are constant operations to route out criminals, drug and arms traffickers who may be involved in terrorism. This state of affairs has affected the Moslem community in Kenya, which feels persecuted in the name of fighting terrorism. The United States, Britain and the West have declared the Greater Horn of Africa as a terrorist-infested region.

Fighting international terrorism has opened a new chapter in the US/West relations with the Greater Horn, with great consequences. On his tour of Africa in July 2003, President Bush drummed up the anti- 
terrorism theme in Kampala. Bush visited only Uganda in the Greater Horn. He promised financial, military and economic assistance in fighting terrorism in the region. However, US assistance needs to be focused on preventing terrorism at the economic and political levels rather than by the military. More assistance should go into building nation-states, regional development, security and cooperation than military and intelligence hardware.

Terrorism, terror alerts and insecurity in the region hamper and affect investment, tourism and development. At the same time, regional relationships between nations are affected due to the fear of the spread of terrorism. For example, Kenya has been declared a key terrorist target by the West. This state of affairs was worsened by the US war against Iraq and the Mombasa Hotel bombing (2003) in the region and globally. Uganda has also been involved in anti-terrorist operations in Kampala by targeting non-nationals from Somali and Ethiopia.

In September 2003, Djibouti, due to pressure from the United States, gave a deadline for all non-nationals (illegal migrants) to leave the country. Most of these migrants originate from Somalia, Ethiopia, Eritrea and the Sudan. The expelled persons have created returnee problems for countries which are already affected by famine and hunger. ${ }^{22}$ The struggle over the US anti-terror monies and military assistance in the region has affected the configuration of political forces locally and regionally. Terrorist alerts and anti-terrorist laws are quickly passed, at the pleasure of the US. However, such approaches generate a lot of tensions in the political economies of countries in the region, as already noted.

At the continental level, the new AU has attempted to handle the issues and politics of terrorism through declarations and meetings. For example, the Algiers Convention on the Prevention and Combating of Terrorism and other relevant international instruments (August 2002) and the Fifth Extra-Ordinary Session of the Central Organ of the OAU mechanism for Conflict Prevention, Management Resolution at a ministerial level (November 2001) are some of the direct legal and diplomatic steps taken at the continental level.

\section{Concluding Note}

The Greater Horn of Africa has many of the negative elements which characterise much of the continent. This region is infested by natural, man-made, political and security quagmires, which demand serious aca- 
demic investigation and common practical solutions. The commonality of problems demands some form of regional economic, trade, political, security cooperation and revisitation with the assistance of the international community. The interplay between Power, (In) Security and Ex/ InClusion and Marginalization in the nation-states of the region needs to be addressed in order to reduce the tendencies towards extremism, fundamentalism and terrorism in the Greater Horn.

It is true that the region has shared history, culture, natural resources, and governance. However, increased intrastate and interstate conflicts and wars fed by fundamentalism, international terrorism and Great Power involvements pose a challenge to national and regional stability and development. Attempts have been made to resolve the outstanding problems through dialogue, negotiations, discourses at state initiatives, regional and continental institutional arrangements and even involving the international community, but these solutions do not seem to be working. The New AU, EAC, IGAD, COMESA, and the NEPAD are all attempts to address the economic and political imbroglios which characterise the region and the continent. The way forward towards regional integration should address some of the issues of democracy and security. Academia should engage in serious research, debate and dissemination of ideas on the issue of security in the region and the continent. Security and democracy should be at the core of debate regarding regional integration and the unity of the continent. It might seem crude to debate regional integration while the integrating units are collapsing, at war and in economic, social and political dire straits. African leadership, which should be the vanguard of the new Africa, has fallen prey to personal and selfish interests. It is the humble contribution of academia to stand up to be counted in the areas of restoration of democracy, security and the economy of Africa. No political struggle is not a protracted one; however, the struggle must vigorously and rigorously continue on the academic plane.

The struggle against international terrorism in the region needs the concerted efforts of all nations at national, regional, continental and global levels. Regional and national initiatives are crucial in tackling this new political scourge in the Greater Horn of Africa. Uganda, which is sandwiched between the Great Lakes region and the Greater Horn, has a crucial role to play in fighting the politics of terrorism. The antiterrorism fight should not compromise good neighbourliness, regional 
cooperation, security, human rights, democracy and development in Uganda and the Great Horn of Africa.

\section{Notes}

1. A. K.K. Mukwaya, 2002, 'The Uganda Movementocracy Foreign Policy and the Great Lakes region: An Analytical Overview', Paper presented at the Mwalimu Nyerere Foundation conference, Kampala, 3-10 April, p.6.

2. Ibid., p.6.

3. Ibid., p.7.

4. O. Nnoli, 1992, Introduction to Politics, (London, Longman) and African International Relations, 1987, London, Longman.

5. Yashpal, A. Tandon and D. Chandarana, 1974, Horizons of African Diplomacy, Nairobi, East African Literature Bureau.

6. J. Spanier, 1972, Games Nations Play, New York, Praeger, p.227.

7. Y. K. Museveni, 1992, What is Africa's Problem?, Kampala, NRM Publications p.52, 21 .

8. Y. K. Museveni, 1985, Ten-Point Programme of NRM, Kampala, NRM Publications.

9. Hans J. Morgenthau. 1978. Politics Among Nations, New York, Alfred A. Knopf, p.150.

10. D. Sanders, 1990, Losing an Empire Finding a Role, British Foreign Policy since 1945, London, Macmillan, p.12.

11. Ibid, pp.12-13.

12. Ibid pp.12-13.

13. A. Narman, 1997, 'Development Thinking: Bridging the gap between theory and practice', Geografiska Annaler, Series B, Human Geography, Svenska, vol. 79B, No. 4, pp. $217-225$.

14. Ibid. p.217.

15. Ibid, p. 222 .

16. Ibid, p.228.

17. Ibid., pp. $217-225$.

18. B. Buzan, 1991, People, States and Fear: An Agenda for International Security Studies in the Post-Cold War Era, (2nd ed), Boulder, Lynne Reinner Publishers, p. 190.

19. The Independent (London), 22 February 1987.

20. The Times (London), 11 February 1986.

21. Anti-Terrorist Act (Uganda), 2002.

22. The Monitor (Kampala), I September 2003. 
